\title{
PELACURAN DI NEGERI SELAT
}

\author{
Nurul Asnida Abu Bakar
}

\begin{abstract}
This article examines the history of prostitution in the Straits Settlements which comprised Singapore, Penang and Malacca. In order to have clear pictures on the women oldest profession, the statistics on prostitution activities based on primary sources were included. Further, the spread of diseases such as syphilis and gonorrhea were discussed to show the impact of prostitution activities in the Straits Settlements during the period examined. According to the records available for 1916, Singapore became the centre of prostitution activities during this period and these activities involved mainly Chinese and Japanese women. Similar developments took place in Penang where these two ethnic groups also dominated the prostitution activities. It is believed that the women were brought to the Straits Settlements as prostitutes in the $19^{\text {th }}$ century was partly due to the disproportionately lower number of female immigrants in these states compared to male immigrant.
\end{abstract}

\section{Pengenalan}

Pelacuran dianggap sebagai profesion tertua dan dilihat sebagai penyakit sosial yang melanda hampir seluruh dunia. Pelacuran merujuk kepada kata akar "lacur" yang bererti jalang atau sundal' yang lazimnya dikaitkan dengan wanita. Di Tanah Melayu, penglibatan wanita Melayu di dalam dunia pelacuran telah wujud sebelum kedatangan British lagi. Ini adalah kerana sistem perhambaan yang wujud ketika itu seolah-olah mempunyai kaitan langsung dengan institusi pelacuran. Misalnya menurut catatan yang dibuat oleh
seorang hamba; 
Kerja2 kami yang utama ia-lah memasak, mengasoh, mengangkat ayer, membelah kayu api, menumbok padi, dan di-waktu malam hari kami boleh melachorkan diri, menyerahkan separoh dari pendapatan ini kapada Raja dan yang baki-nya itu di-guna-kan untuk membekalkan pakaian kami dan makanan untok istana Sultan dan hamba2nya. Jikalau kami gagal mendapatkan wang melalui pelachoran kami akan di-sebat dengan rotan yang besar dan kadang2-nya di-pukul dengan semambu di-atas kepala dan belakang kami. Kami di-halang mengahwini orang yang hendak mengambil kami sa-bagai isteri-nya. ${ }^{2}$

Berdasarkan kepada kenyataan di atas memperlihatkan bahawa golongan hamba tidak hanya melakukan kerja-kerja harian sahaja malah ada di kalangan mereka dijadikan pelacur pada sebelah malamnya. Hukuman akan diberikan jika mereka ingkar melaksanakan tugas tersebut. Namun dalam tempoh ini pelacuran jarang diperkatakan disebabkan kemunculannya masih diperingkat awal.

Rata-rata faktor utama yang membawa kepada perkembangan pelacuran adalah disebabkan oleh ketidakseimbangan jantina di antara lelaki dan perempuan yang mana jumlah imigran lelaki dilihat mengatasi jumlah imigran perempuan kesan daripada perkembangan ekonomi. Untuk itu, perbincangan ini akan diperpanjangkan di Negerinegeri Selat dengan melihat kepada perkembangan aktiviti pelacuran di negeri-negeri tersebut.

\section{Perkembangan Pelacuran di Negeri-negeri Selat}

Awalnya pada tahun 1780 lagi ciri-ciri kewujudan aktiviti pelacuran telah dikenalpasti di Tanah Melayu. ${ }^{3}$ Dalam laporan yang dibuat kepada Sir C.J Tarring, Chairman untuk The Association for Moral and Social Hygience yang bertajuk "Keadaan Pelacuran di Singapura", John Cowen melaporkan:

... Singapore has become the centre of another kind of slave trade, namely an enormous in prostitution, the abolition which is sought by persons who base their view and actions on Christian teaching, as Raffles did, and who are met with the same answer... that however laudable their motives may be, their policy is disadvantageous to the colony and impracticable at the moment. ${ }^{4}$

Pada tahap awal bilangan mereka yang terlibat dalam pelacuran di Singapura adalah kecil. Namun selepas kedatangan imigran khususnya dari negara China, India dan Eropah keperluan untuk melanggani pelacur semakin meningkat. Keperluan sebagai tenaga buruh yang tinggi akibat perkembangan ekonomi telah memaksa British mengimport lebih ramai tenaga buruh dari luar. Juster 
imigran lelaki yang dibawa masuk telah ditetapkan untuk bekerja di sektor perlombongan manakala imigran wanita pula dibawa ke rumah pelacuran sebagai pelacur. ${ }^{5}$

Secara amnya, kumpulan pelacur yang dikenalpasti terdiri daripada masyarakat Cina, ${ }^{6}$ Melayu, India, Serani, Eropah dan Jepun. ${ }^{7}$ Bagi masyarakat Cina pelacuran dianggap sebagai perkara biasa. Hal ini kerana kegiatan pelacuran di China turut diceburi oleh wanitawanita yang sudah berkahwin dan telah mempunyai anak. ${ }^{8}$ Selain itu, pelacur digelar sebagai Mui Tsai dan Chabokan di Negeri-negeri Selat. Wanita yang berasal daripada strata sosial yang rendah akan dijual sebagai Mui Tsai dan Chabokan di Negeri-negeri Selat tersebut. Mui Tsai membawa maksud "a euphemism disguising a form of servitude", manakala Chabokan merupakan gadis yang berasal daripada keluarga miskin yang diberikan tugas melakukan kerja-kerja di rumah. ${ }^{9}$ Walaupun demikian, terdapat juga di kalangan mereka ini dijadikan sebagai pelacur.

Imigran wanita dibawa masuk ke Negeri-negeri Selat dan Negeri-negeri Melayu pada abad ke-19 disebabkan masalah ketidakseimbangan jantina di antara lelaki dan perempuan yang mana jumlah imigran lelaki dilihat mengatasi jumlah imigran wanita (Lihat jadual 1). Keadaan ini akhirnya membuka ruang kepada golongan wanita dan gadis melibatkan diri dalam kegiatan pelacuran. J. D. Vaughan's dalam bukunya bertajuk The Manners and Custom of the Chinese of the Straits Settlement berpendapat:

None of the middle or upper classes nor women emigrate. There is no law in China prohibiting the emigration of women, or any particular class, but there is a reluctance on the part of the Chinese to quit their native country, and it is only dire neccessity that compels the poor to do so. Of late years, many women have come down, chiefly prostitutes, who are bought by brothel keepers to carry on their trade here. The writer knows no instance of respectables women emigrating with her husband. ${ }^{10}$

Kenyataan di atas jelas menunjukkan bahawa penghijrahan imigran wanita memang tidak digalakkan pada peringkat awal. Namun, faktor desakan di negara asal seperti bencana alam dan kemiskinan telah memaksa mereka berhijrah keluar dalam kerangka kesusahan ini dan akhirnya terlibat dalam kancah
pelacuran.

Berdasarkan kepada jadual di bawah, majoriti penduduk di Singapura antara tahun 1871 hingga 1901 adalah di kalangan masyarakat Cina. Apabila melihat kepada jumlah keseluruhan penduduk di Singapura, hampir setengah penduduknya adalah di 
Jadual 1: Jumlah Penduduk Cina di Singapura, 1871-1901

\begin{tabular}{|c|c|c|c|c|c|c|c|}
\hline \multirow{3}{*}{ Tahun } & \multicolumn{4}{|c|}{ Penduduk Cina } & \multirow{3}{*}{$\begin{array}{l}\text { Jumlah } \\
\text { Penduduk } \\
\text { Cina }\end{array}$} & \multirow{3}{*}{$\begin{array}{l}\text { Jumlah } \\
\text { Penduduk }\end{array}$} & \multirow{3}{*}{$\begin{array}{l}\text { Peratus } \\
\text { Penduduk } \\
\text { Cina }\end{array}$} \\
\hline & \multicolumn{2}{|c|}{$\begin{array}{l}15 \text { tahun dan } \\
\text { ke atas }\end{array}$} & \multicolumn{2}{|c|}{$\begin{array}{l}\text { Bawah } \\
15 \text { tahun }\end{array}$} & & & \\
\hline & Lelaki & Wanita & Lelaki & Wanita & & & \\
\hline 1871 & 43,678 & 5,200 & 3,426 & 3,268 & 54,572 & 97,111 & 56.2 \\
\hline 1881 & 67,894 & 9,839 & 4,677 & 4,356 & 86,766 & 139,208 & 62.8 \\
\hline 1891 & 93,972 & 15,616 & 6,474 & 5,846 & 121,908 & 184,554 & 66.3 \\
\hline 1901 & 118,196 & 23,956 & 12,171 & 9,718 & 164,041 & 228,555 & 71.8 \\
\hline
\end{tabular}

Sumber: Dipetik dari Ng Siew Yoong, Chinese Protectorate (1877-1900), Latihan Ilmiah, Singapore: University Malaya,1955.

kalangan masyarakat Cina menjadikan mereka kaum yang paling ramai menetap di Singapura dalam tahun 1871 hingga 1901.

Jadual di atas turut menyatakan pecahan umur yang dibahagikan kepada dua kategori iaitu umur 15 tahun ke atas dan bawah 15 tahun untuk memudahkan pemahaman. Selain itu, turut diberikan statistik jumlah penduduk bagi tempoh selang sepuluh tahun iaitu tahun 1901, 1891 dan 1881. Secara keseluruhannya ia secara jelas menunjukkan ketidakseimbangan jantina di antara kaum lelaki dan perempuan. Berpandukan kepada keempat-empat tahun yang dinyatakan di atas, didapati tahun 1901 mencatatkan jumlah ketidakseimbangan yang jelas. Pada tahun tersebut, jumlah penduduk Cina lelaki dalam kategori usia 15 tahun ke atas adalah sebanyak 118, 196 orang berbanding kaum perempuan yang hanya berjumlah 23,956 orang. Perbezaan jumlah antara lelaki dan wanita adalah sebanyak 94,240 orang. Berbanding kategori umur bawah 15 tahun, bilangan kaum lelaki adalah seramai 12,171 orang manakala wanita pula seramai 9,718 orang. Julat perbezaan antara lelaki dan wanita bagi kategori ini adalah seramai 2 , 453 orang.

Mengikut perkiraan bagi tahun 1891, seramai 93, 972 orang kaum lelaki dan 15, 616 orang kaum wanita berada dalam kategori umur 15 tahun dan ke atas, manakala bagi kategori umur bawah 15 tahun, seramai 6,474 orang kaum lelaki dan 5, 846 orang kaum wanita. Terdapat jurang perbezaan yang jelas di antara lelaki dan wanita bagi data yang diperoleh untuk tahun 1891 iaitu 78, 356 orang untuk kategori umur 15 tahun dan ke atas manakala 628 orang bagi kategori 
umur bawah 15 tahun. Bagi tahun 1881 pula jumlah penduduk Cina bagi kaum lelaki dalam kategori umur 15 tahun dan ke atas adalah seramai 67,894 orang berbanding 9,839 orang kaum wanita dalam kategori kumpulan umur yang sama. Julat perbezaan adalah seramai 58,055 orang antara lelaki dan wanita. Kategori umur bawah 15 tahun pula, 4, 677 orang merupakan kaum lelaki dan hanya 4, 356 orang kaum wanita. Untuk tahun ini, jumlah perbezaan antara lelaki dan wanita tidak tinggi iaitu seramai 321 orang jika dibandingkan dengan tahun 1871, 1891 dan 1901.

Setelah meneliti data-data yang diperolehi, ketidakseimbangan yang jelas telah berlaku di antara kaum lelaki dan wanita di Singapura dalam tahun 1871 hingga 1901 . Sememangnya faktor perkembangan ekonomi yang pesat menjadi faktor pendesak yang akhirnya mewujudkan ketidakseimbangan kaum antara lelaki dan wanita.

Selain itu, imigran lelaki yang datang rata-ratanya merupakan golongan yang masih bujang. Bagi golongan yang telah berkahwin, mereka terpaksa meninggalkan isteri di negara masing-masing. Ini disebabkan oleh faktor kos pengangkutan dan sara hidup yang tinggi. Sehubungan dengan itu, pelacur diperlukan sebagai hiburan selain memenuhi tuntutan batiniah. Dasar British yang mahukan tenaga buruh yang murah juga dianggap sebagai salah satu penyumbang kepada perkembangan aktiviti pelacuran. Majoriti imigran luar yang dibawa masuk adalah dari bahagian selatan negara China seperti dari daerah Kwantung, Kwangsi, Hainan dan Formosa. ${ }^{11}$ (Lihat Peta 1).

Peta 1: Wilayah-wilayah utama asal usul masyarakat Cina di Tanah Melayu

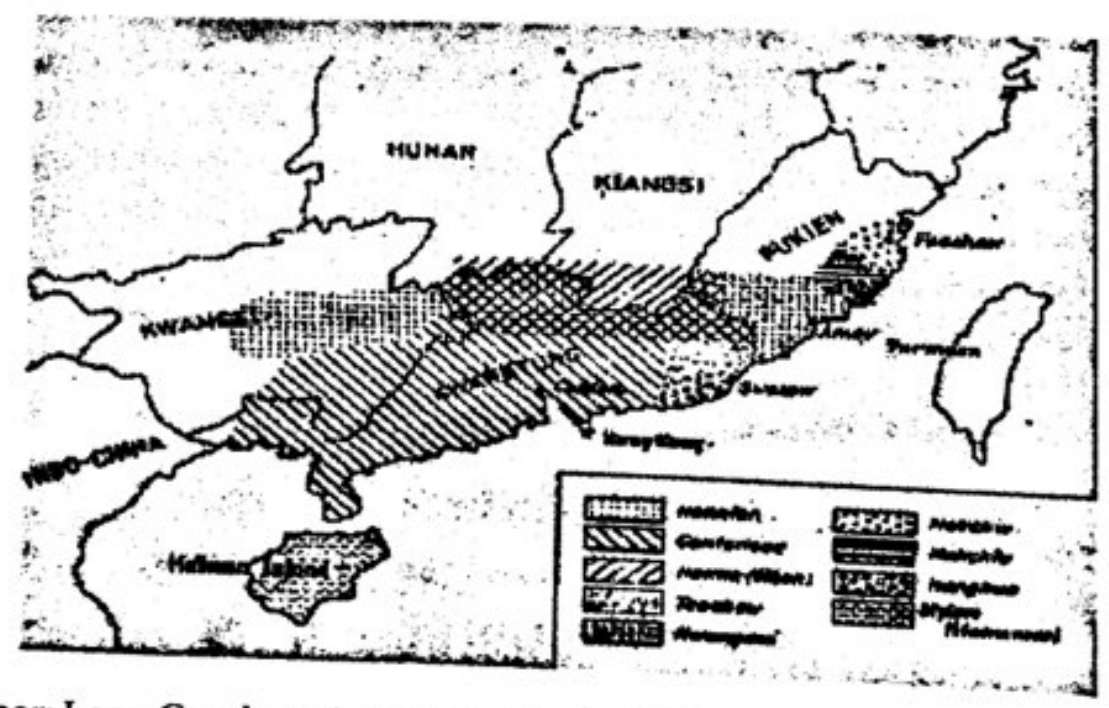


Pada peringkat awalnya, perkembangan pelacuran dilihat lebih rancak di Negeri-negeri Selat berbanding Negeri-negeri Melayu lain. Keadaan ini disebabkan oleh perkembangan ekonomi dan kemasukan imigran Cina dan imigran India di ketiga-tiga negeri ini iaitu Pulau Pinang, Singapura dan Melaka ${ }^{12}$ yang dilihat mendahului Negerinegeri Melayu yang lain. Pembukaan Pulau Pinang pada tahun 1786 sebagai contoh, menyaksikan kemasukan orang Cina yang semakin ramai. Statistik juga menunjukkan pada pertengahan abad ke-19 nisbah lelaki kepada wanita adalah 50:1 pada tahun $1879,40: 1$ pada tahun 1883 dan 20:1 di antara tahun 1892-1902. Jurang nisbah ini menunjukkan bahawa bilangan golongan lelaki jauh mengatasi bilangan golongan wanita pada masa tersebut. ${ }^{13}$

Selain itu, imigran yang datang ke Pulau Pinang sebelum 1881 tidak dilindungi oleh mana-mana penguatkuasaan sehingga munculnya Immigrant and Anti-Crimping Ordinance Bill pada tahun 1877. Objektif utamanya adalah melindungi masyarakat Cina daripada cengkaman kongsi gelap. Tanpa sebarang penguatkuasaan undangundang, penghijrahan di kalangan imigran-imigran tersebut lebih mudah berlaku. Bagi kongsi gelap yang wujud pada waktu itu pula, mereka dianggap sebagai "had fostered their tentacles on the brothels and the recruitment of women and girls for immoral purpose" ${ }^{14}$ Kenyataan ini jelas ditunjukkan menerusi perkaitan rapat kongsi gelap dengan rumah pelacuran yang melibatkan wanita dan gadis ke dalam aktiviti yang tidak bermoral ini. Keadaan yang sama berlaku apabila Singapura dibuka pada tahun 1819 (Lihat jadual 2).

Kedatangan golongan imigran ini pada awalnya bertujuan memenuhi keperluan tenaga buruh yang diperlukan. Saudagarsaudagar Cina yang paling awal menetap di Singapura merupakan saudagar dari Melaka yang biasanya dikenali sebagai 'baba' pada abad ke-19. Sebelum abad ke-18, populasi orang Cina yang menetap di Melaka agak kecil bilangannya. Hal ini kerana pada masa itu bilangan penduduk Cina jauh lebih ramai di negeri-negeri Melayu bahagian timur seperti di Kuala Kelantan, Kuala Terengganu dan Kuala Pahang. ${ }^{15}$ Saudagar Cina ini secara aktif melibatkan diri dalam hal-hal yang berkaitan perniagaan. 
Jadual 2: Jumlah penduduk Cina dan India di Negeri-negeri Selat, 1871.

\begin{tabular}{lccc}
\hline Bangsa & Pulau Pinang & Singapura & Melaka \\
\hline Cina & 36,561 & 54,572 & 13,482 \\
India & 18,611 & 11,501 & 3,278 \\
\hline
\end{tabular}

Sumber: Ooi Jin Bee, Bumi, Pendudok dan Ekonomi di- Tanah Melayu, Kuala Lumpur: Dewan Bahasa dan Pustaka, 1968, hlm. 114.

Jadual di atas jelas menunjukkan bilangan penduduk Cina dan India yang agak ramai di Negeri Selat dalam tahun 1871. Berdasarkan kepada jadual ini, kaum Cina dilihat lebih dominan di Singapura berbanding di Pulau Pinang dan Melaka iaitu seramai 54, 572 orang. Terdapat perbezaan seramai 18,011 orang jika jumlah ini dibandingkan dengan bilangan di Pulau Pinang dan 41,090 orang di Melaka. Jumlah kaum Cina di Pulau Pinang adalah seramai 36,561 orang iaitu melebihi bilangan yang terdapat di Melaka yang hanya berjumlah 13, 482 orang sebanyak 23,079 orang. Bagi kaum India, tumpuan mereka dilihat lebih ramai di Pulau Pinang diikuti di Singapura dan Melaka. Bilangan kaum India adalah seramai 18, 611 orang di Pulau Pinang iaitu berbeza sebanyak 7, 110 orang dengan jumlah kaum India di Singapura dan 15,333 orang di Melaka. Julat perbezaan di antara penduduk India di Singapura yang berjumlah 11, 501 orang dengan penduduk India di Melaka yang keseluruhannya berjumlah 3, 278 orang adalah seramai 8,223 orang.

Sememangnya kaum Cina lebih dominan di Singapura berbanding di Pulau Pinang dan Melaka atas faktor perkembangan ekonomi yang pesat selain kepentingan politik dan sosial yang berlaku pada masa tersebut. Berbanding kaum India di Pulau Pinang, keperluan kaum Cina pada dasarnya hanyalah bagi memenuhi keperluan sebagai tentera upahan. Hal yang demikian menyebabkan golongan ini meneruskan tradisi dalam menjadikan Pulau Pinang
sebagai pilihan utama selain kepentingan ekonomi.

Aktiviti pelacuran lazimnya dipercayai berkait rapat dengan Chinese Protectorate. Di Singapura, ia berfungsi dalam hal-hal yang berkaitan dengan imigran Cina, perdagangan haram di kalangan wanita dan gadis serta kongsi-kongsi gelap Cina. Peranan "Chinese Protectorate" adalah diperlukan di bawah Dangerous Society Suppression Ordinance (DSSO). ${ }^{16}$ Badan seperti ini dilihat bertanggungjawab sepenuhnya terhadap kebajikan orang-orang Cina. Untuk tujuan itu, 
Chinese Protectorate ditubuhkan pada tahun 1877 bagi menguruskan hal-hal yang berkaitan dengan masyarakat Cina. W.A. Pickering ${ }^{17}$ dilantik sebagai Protector of Chinese ${ }^{18}$ yang pertama. Kemasukan wanita $^{19}$ dan gadis $^{20}$ ke Singapura secara haram untuk memenuhi keperluan di rumah-rumah pelacuran menyebabkan peranan Chinese Protectorate dilihat sebagai satu tindakan yang wajar. Mereka yang berniat untuk berhijrah akan disiasat secara telus sebelum datang ke Tanah Melayu. Bagi wanita dan gadis yang dikenalpasti bakal terlibat dalam aktiviti pelacuran, penghantaran pulang ke negara asal akan dilakukan. Kebanyakan imigran wanita ini dikenalpasti telah diculik dan dipaksa oleh pihak tertentu untuk dijadikan pelacur. Selain itu, mereka turut dijanjikan pekerjaan yang baik dengan gaji yang lumayan. Tindakan ini bersesuaian dengan tanggungjawab Protector dalam menghindari kemasukan wanita dan gadis secara haram. Di Pulau Pinang pula, Protectorate Office dibina pada tahun 1881 dan ia memegang peranan yang sama dengan Chinese Ptotectorate di Singapura. E. Karl merupakan seorang saudagar Cina telah dilantik sebagai Assistant Protector yang pertama. ${ }^{21}$

-Kemunculan rumah-rumah pelacuran di Negeri-negeri Selat turut membuka ruang kepada perkembangan kegiatan pelacuran di negerinegeri tersebut. Rumah-rumah pelacuran telah dijadikan sebagai tempat kegiatan pelacuran beroperasi dalam memberikan perkhidmatan seksual. Selain itu, rumah-rumah urut kadang kala menawarkan perkhidmatan yang sama. Para pelacur yang dibawa ke Negeri-negeri Selat lazimnya berasal dari negara China dan Jepun. Wanita-wanita ini dibawa dari daerah China Selatan dan Hong Kong. ${ }^{2}$ Untuk memenuhi keperluan batiniah, pelacur memang diperlukan. Peranan Negeri-negeri Selat sebagai sebuah bandar pelabuhan dan tempat kapal-kapal berlabuh merupakan antara faktor kepada keperluan kegiatan pelacuran. Keadaan ini telah menjadikannya tumpuan dan alasan kelasi-kelasi kapal yang inginkan hiburan untuk berlabuh di pelabuhan Negeri-negeri Selat. ${ }^{23}$

Ketidakseimbangan jantina di antara imigran lelaki dan imigran wanita yang memperlihatkan imigran lelaki mengatasi wanita sebagai tenaga buruh dianggap sebagai salah satu faktor penyumbang kepada perkembangan aktiviti pelacuran. Lebih-lebih lagi kedatangan mereka tanpa membawa anak dan isteri menyebabkan buruh-buruh yang tidak mempunyai isteri mencari pelacur untuk memuaskan nafsu seks selain ia membuka peluang kepada penganjur wanita dan gadis menjual perkhidmatan seks yang amat diperlukan oleh buruh-buruh ini. Untuk memenuhi 'pasaran' yang berlebihan, penganjur ini telah membawa masuk lebih ramai wanita dan gadis dari Negara China dan Hong Kong untuk melacur di Tanah Melayu. ${ }^{24}$ Contohnya di Pulau Pinang terdapat 
empat hingga lima orang lelaki Cina bagi bagi setiap pelacur wanita di antara tahun 1870 hingga $1880 . .^{25}$

Singapura telah dijadikan sebagai saluran utama bagi pelacur Jepun untuk dibawa ke pelabuhan British di bahagian Timur seperti di Hanoi, Haiphong dan Macao ${ }^{26}$ Kawasan pelacuran yang dikenal pasti di Singapura adalah di sekitar Malay Street, Bugis Street, Hylam Street dan Malabar Street (Lihat jadual 3). ${ }^{27}$ Catatan menunjukkan di Malay Street sahaja jumlah pelacur adalah seramai 200 orang. ${ }^{28}$ Pelacuran di Singapura melibatkan masyarakat dari China, Eropah, India dan Jepun. ${ }^{29}$ Menurut seorang kapten kapal yang telah menetap lama di Singapura "... there were 1500 Japanese prostitution alone in Singapore". ${ }^{30}$ Selain itu kanak-kanak turut terlibat dalam kegiatan pelacuran dan ditempatkan di rumah pelacuran Cina di Smith Street, Singapura. ${ }^{31}$

Jadual 3: Lokasi aktiviti pelacuran di Singapura

\begin{tabular}{|c|c|}
\hline \multirow[t]{3}{*}{ Malay Street } & - No. 11/4 Malay Street \\
\hline & $\begin{array}{l}\text { Dua orang kanak-kanak berusia 6-8 tahun terlibat } \\
\text { dengan kegiatan pelacuran. }\end{array}$ \\
\hline & $\begin{array}{l}\text { No.25 Malay Stree tDidaftarkan sebagai } \\
\text { kedai makan namun beroperasi sebagai rumah } \\
\text { pelacuran. }\end{array}$ \\
\hline Bugis Street & $\begin{array}{l}\text { Majoritinya adalah masyarakat Cina dan Jepun. } \\
\text { Terdapat kedai makan yang dijadikan sebagai } \\
\text { rumah pelacuran. }\end{array}$ \\
\hline Hylam Street & $\begin{array}{l}\text { Terdapat } 35 \text { buah rumah pelacuran dengan } \\
\text { disertai } 5 \text { hingga } 10 \text { orang pelacur setiap rumah } \\
\text { pelacuran. Tiga hingga empat buah rumah } \\
\text { pelacuran telah dikhaskan untuk masyarakat luar } \\
\text { seperti Jawa, Rusia dan Rom. }\end{array}$ \\
\hline Malabar Steet & $\begin{array}{l}\text { Terdapat kira-kira } 40 \text { buah rumah pelacuran. Bar } \\
\text { yang dikenali sebagai "The Moonshine" dipenuhi } \\
\text { dengan pelacur Cina dan Jepun. }\end{array}$ \\
\hline
\end{tabular}

Sumber: CO273/Vol. 453, Prostitution in the Colony, 1916.

Ah $K u$ pula digunakan sebagai simbol yang merujuk kepada pelacur Cina manakala Karayuki-San merujuk kepada pelacur di kalangan masyarakat Jepun di Singapura antara tahun 1870 dan 1940.32 Kesemua pelacur dan rumah pelacuran di Singapura perlu didaftarkan 
di bawah Ordinan Penyakit Berjangkit. Namun,ordinan ini kemudiannya dipinda pada tahun 1887 bagi pelacur dan 1894 bagi rumah pelacuran yang mana kesemua pelacur dan rumah pelacuran tidak lagi berada di bawah Ordinan Penyakit Berjangkit. ${ }^{33}$

Pada tahun 1864, terdapat 349 buah rumah pelacuran yang beroperasi di Singapura dengan bilangan pelacur berdaftar seramai 2 , 061 orang. Jumlah ini kemudiannya meningkat menjadi 1, 635 buah pada tahun 1871. Aktiviti pelacuran ketika ini bukan sahaja beroperasi di rumah-rumah pelacuran tetapi juga di rumah-rumah awam yang didalangi oleh orang perseorangan. Kewujudan rumah awam ini berleluasa selepas pemansuhan Ordinan Penyakit Berjangkit. Laporan pihak polis membuktikan terdapat 298 buah rumah awam telah dibina bagi tujuan pelacuran dan ia melibatkan pelacur seramai 228 bangsa Cina, ${ }^{34} 26$ bangsa Jepun, 22 bangsa Eropah,, 10 bangsa India dan 12 bangsa Melayu. ${ }^{36}$

Di Pulau Pinang statistik menunjukkan terdapat 281 orang pelacur yang dikenalpasti pada tahun 1871 . Secara amnya, keaktifan kegiatan pelacuran ini dapat dikesan di rumah pelacuran yang melibatkan bangsa Cina dan Jepun. Antara yang tersenarai adalah kawasan rumah pelacuran Cina di Bukit Mertajam dan Nibong Tebal. ${ }^{37}$ Kedua-dua kawasan ini majoriti penduduknya adalah masyarakat Cina. Keadaan ini masih dapat dilihat sehingga kini yang mana penduduk di situ kebanyakannya adalah masyarakat Cina.

Keadaan yang sama turut berlaku di Melaka apabila terdapat 151 orang pelacur pada tahun 1871 dan jumlah ini kemudiannya telah meningkat menjadi 173 pelacur pada tahun 1881. Berbeza di Pulau Pinang, laporan polis mendapati terdapat 69 orang pelacur Cina berkhidmat di rumah awam. Pelacur berbangsa Jepun pula dikesan berkhidmat di rumah pelacuran Jepun. ${ }^{38}$

Kesan aktiviti pelacuran telah membawa kepada kemunculan penyakit kelamin (venereal disease). Penyakit kelamin tergolong dalam Sexually Transmitted Disease (STDs) dan ianya disebabkan oleh hubungan kelamin antara lelaki dan perempuan yang melibatkan organisma seperti virus, bakteria protozoa dan kulat. ${ }^{39}$ Antara penyakit yang tergolong dalam kategori penyakit ini ialah Gonorea, ${ }^{+0}$ Sifilis, ${ }^{41}$ Chancroid, Granuloma Inguinal dan Iympnogranuloma. ${ }^{42}$ Wanita yang melibatkan diri dalam aktiviti pelacuran lazimnya akan dijangkiti penyakit kelamin ekoran daripada perhubungan seksual yang aktif. Antara tahun 1884 hingga 1888, hampir 50 peratus kaum lelaki yang melanggani pelacur dijangkiti kuman gonorea di Singapura. Di Pulau Pinang pula hanya 25 peratus sahaja yang dikesan menghidap penyakit kelamin pada tahun 1897.43 Tiga buah hospital di Negeri-negeri Selat iaitu Hospital Kandang Kerbau, Singapura, Hospital Pulau Pinang dan 
Hospital Melaka dilihat memainkan peranan penting dalam memberikan rawatan kepada para penghidap penyakit kelamin dari tahun 1888 sehingga 1892 (Lihat jadual 4a, 4b dan 4c).

Selain itu, penularan penyakit kelamin dilihat semakin kritikal sehingga memaksa pihak British memberikan perkhidmatan pemeriksaan percuma kepada pelacur-pelacur di hospital-hospital awam lebih-lebih lagi selepas Ordinan Penyakit Berjangkit diwujudkan pada tahun 1870.44 (Lihat jadual 5) Melalui pemeriksaan yang dilakukan, setiap pelacur harus mendaftar untuk diperiksa kesihatannya bagi tempoh sekali sebulan. Ini menunjukkan kesungguhan pihak British dalam mengatasi penularan penyakit kelamin khususnya di kalangan pelacur. Beberapa langkah telah diambil seperti menggabungkan undang-undang tempatan dengan undang-undang British untuk mengawasi rumah-rumah pelacuran sebagai hukuman kesalahan, menutup rumah-rumah pelacuran dan menguatkuasaan undang-undang kepada pelacur dan 'orang tengah' yang menjalankan kegiatan pelacuran. ${ }^{45}$

Jadual di bawah jelas menunjukkan bahawa aktiviti pelacuran telah membawa kepada penularan penyakit kelamin. Keadaan ini terbukti menerusi data yang diperoleh dari hospital awam di Singapura pada tahun 1890. Melihat kepada jumlah pesakit yang dilaporkan iaitu seramai 567 orang, ia cukup untuk membuktikan bahawa kerancakan aktiviti pelacuran telah memberikan kesan yang negatif iaitu merebaknya penyakit kelamin yang akhirnya memaksa beberapa langkah pengawalan dilakukan sebagai usaha mengatasinya.

Menurut Sd. Max F. Simon, Principal Civil Medical Officer berdasarkan laporan di tiga buah negeri Selat pada tahun 1892, wanita yang dilaporkan menerima rawatan dan pemeriksaan bagi penyakit kelamin secara sukarela di Singapura ialah seramai 24 orang dengan seorang berbangsa Eropah, lapan belas orang berbangsa Jepun, lapan orang berbangsa Cina, seorang Melayu dan India. Di Pulau Pinang pula, jumlah yang dilaporkan menerima rawatan adalah seramai 42 orang dengan 29 orang daripadanya disahkan dijangkiti penyakit tersebut. Namun, tiada laporan dikemukakan untuk pengesahan mereka yang menerima rawatan. ${ }^{46}$ 


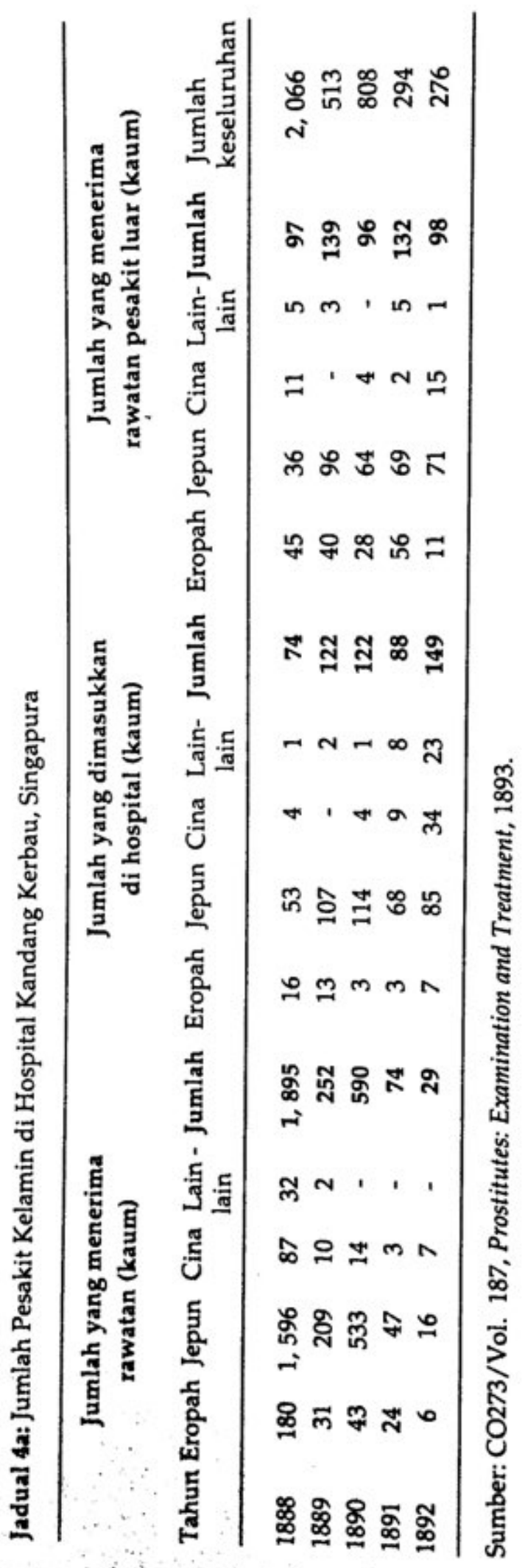




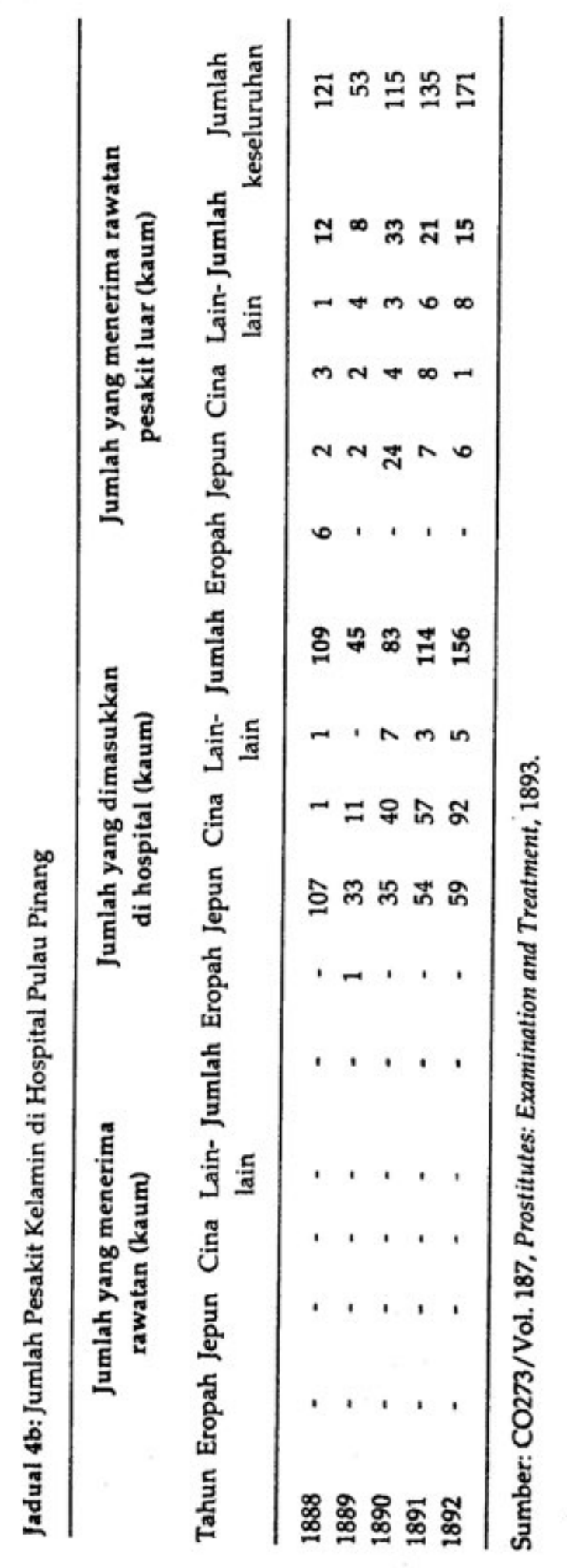




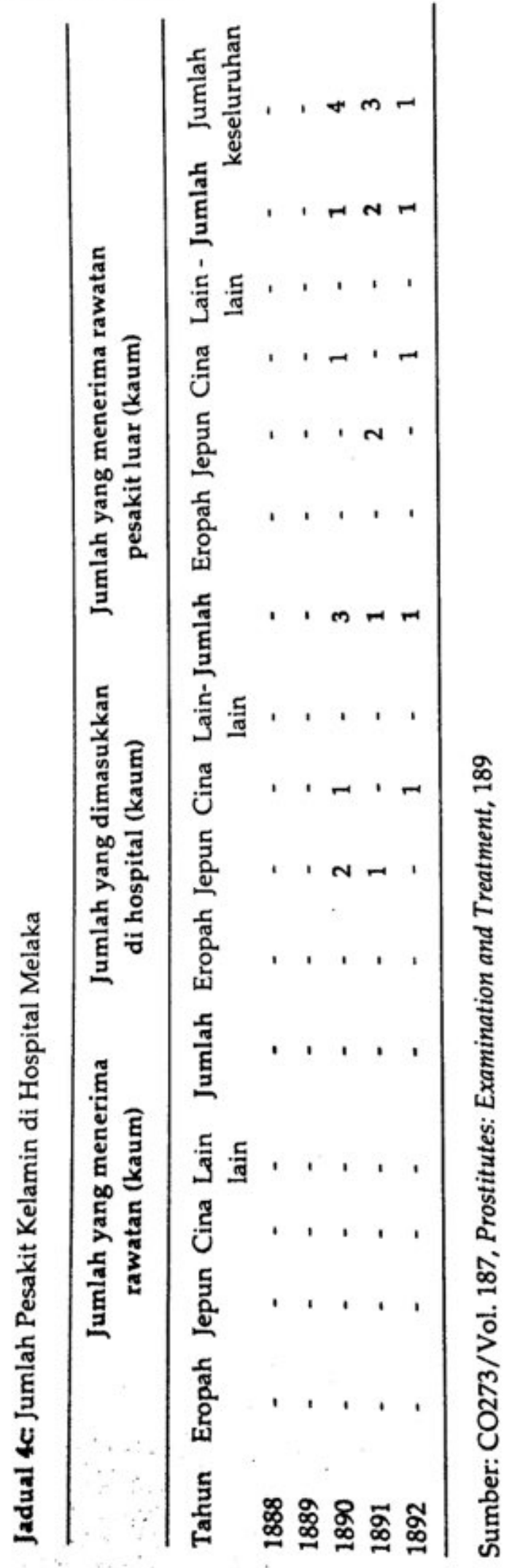


Jadual 5: Jumlah pesakit yang dirawat di hospital awam Singapura pada tahun 1890

\begin{tabular}{lcccc}
\hline Tahun & $\begin{array}{l}\text { Jumlah pesakit } \\
\text { yang di rawat } \\
\text { (wad kelas 1 \& } \\
\text { wad kelas 2) }\end{array}$ & $\begin{array}{l}\text { Wad Kelas 1 } \\
\text { Wad Kelas 2 } \\
\text { (Penyakit Kelamin) } \\
\text { (Jumlah) }\end{array}$ & Tahun & $\begin{array}{l}\text { Wad } \\
\text { Bumiputera } \\
\text { Penyakit } \\
\text { Kelamin (Jumlah) }\end{array}$ \\
\hline 1890 & 567 & 71 & 1885 & 86 \\
\hline
\end{tabular}

Sumber: Tanpa pengarang, Prostitutes and Prostitution in Malaya Between the 1880's and 1930's, Pulau Pinang: Universiti Sains Malaysia, 1973/74, him.10.

\section{Kesimpulan}

Perkembangan pelacuran di Negeri-negeri Selat adalah lebih rancak jika dibandingkan dengan Negeri-negeri Melayu yang lain pada peringkat awalnya. Hal ini disebabkan oleh kepesatan perkembangan ekonomi dan kemasukan imigran khususnya imigran Cina di ketigatiga negeri ini yang dikatakan mendahului Negeri-negeri Melayu yang lain. Selain itu, peranan Negeri Selat sebagai bandar pelabuhan yang dijadikan tempat kapal berlabuh menjadikannya destinasi pilihan kepada kelasi-kelasi kapal yang inginkan hiburan berlabuh di pelabuhan Negeri Selat tersebut.

Pelacuran lazimnya melibatkan golongan wanita. Didapati kebanyakan imigran lelaki yang datang adalah tanpa membawa anak dan isteri. Keadaan ini menyebabkan buruh-buruh yang tidak mempunyai isteri mencari pelacur untuk memuaskan nafsu seks selain ia membuka peluang kepada penganjur wanita dan gadis menjual perkhidmatan seks yang amat diperlukan oleh buruh-buruh ini.

Pelacuran di Negeri-negeri Selat melibatkan kaum Cina, Jepun, Melayu, India, Serani dan Eropah. Para pelacur Cina kebanyakannya berasal dari daerah China Selatan dan Hong Kong. Kemunculan rumah pelacuran di Negeri-negeri Selat telah menggalakkan lagi kegiatan ini kerana ia dipercayai bertindak sebagai pusat pengoperasian kegiatan pelacuran dalam memberikan perkhidmatan seksual. Peranan 'Chinese Protectorate' dilihat wajar berikutan kemasukan wanita dan gadis ke Singapura secara haram untuk memenuhi keperluan di rumah-rumah pelacuran. Dengan berkembangnya aktiviti pelacuran, penyakit kelamin khususnya sifilis dan gonorea semakin berleluasa. Oleh itu tiga buah hospital iaitu Hospital Kandang Kerbau, Singapura, Hospital Pulau Pinang dan Hospital Melaka merupakan antara yang berperanan penting dalam memberikan rawatan kepada para pesakit kelamin. 


\section{Nota}

1 Noresah Baharom, Kamus Dezvan Edisi Ketiga, Kuala Lumpur: Dewan Bahasa Pustaka. 2002, hlm. 742.

2 J.M. Gullick, Sistem Politik Bumiputera Tanah Melayu Barat, Kuala Lumpur: Dewan Bahasa dan Pustaka, 1970, hlm. 166.

3 Tanpa pengarang, Prostitutes and Prostitution in Malaya Between the 1880's and 1930's, Pulau Pinang: Universiti Sains Malaysia, 1973/74, hlm. 1.

$4 \mathrm{CO} 273$ / Vol. 453, Prostitution in the Colony, 1916.

5 Lenore Manderson, Sickness and the State: Health and Illness in Colonial Malaya 1870-1940, Australia: Cambridge University Press, 1996, hlm. 166.

6 Pelacuran di kalangan masyarakat Cina boleh dibahagikan kepada tiga iaitu pelacur yang dijual, pelacur gadaian dan pelacur sukarela. Pelacur yang dijual ialah pelacur yang dibawa dan dikawal di rumah pelacuran yang mana gaji akan ditentukan oleh rumah-rumah pelacuran yang dipertanggungjawabkan manakala pelacur gadaian pula dianggap sebagai pelacur yang bekerja disebabkan hutang yang ditanggung dan sebagai langkah penyelesaian hasil dapatan gaji digunakan sebagai langsaian kepada hutang tersebut. Bagi pelacur sukarela, pelacur tidak terikat dengan sebarang komitmen kepada rumah-rumah pelacuran tetapi perlu memberikan setengah daripada dapatan kepada rumah pelacuran. Pelacur yang tergolong dalam kumpulan ini dijaga hal-hal yang berkaitan tempat tinggal serta kelengkapan-kelengkapan yang berkaitan. Lihat Tanpa pengarang, Prostitutes and Prostitution in Malaya Between the 1880's and 1930's, Pulau Pinang: Universiti Sains Malaysia, 1973/74, hlm.2.

7 Tanpa pengarang, Prostitutes and Prostitution in Malaya Between the 1880's and 1930's, hlm.1.

8 Neil Khor Jin Keong \& Khoo Keat Siew, The Penang Po Leung Kuk: Chinese Women, Prostitution and a Welfare Organisation, Selangor: Selangor Printing Co, 2004, hlm. 40.

$9 \quad$ Ibid., hlm.3.

10 Chin Yoon Fong, "Chinese Female Immigration to Malaya in the 19" and $20^{\text {th }}$ Centuries", HISTORIA, Kuala Lumpur: The Malaysian Historical Society, 1984, hlm. 359.

1 Leon Comber, An Introduction to Chinese Secret Societies in Malaya 18701940, hlm. 22.

12 Pulau Pinang diduduki oleh Syarikat Hindia Timur pada tahun 1786. Sebidang tanah iaitu di Seberang Perai kemudiannya diberikan hak yang sama pada tahun 1800. Pada mulanya jumlah orang Cina dan India tidak begitu ramai namun meningkat secara mendadak dalam tempoh masa yang singkat khususnya di Pulau Pinang dan Seberang Perai. Kebanyakan mereka menjadi peniaga selain bertani. Bagi orang India di Pulau Pinang pula kebanyakan daripada mereka adalah di kalangan saudagar, peniaga kecil dan terdapat juga di kalangan mereka adalah 'sepoy' yang bertanggungjawab menjaga keamanan dan mereka diletakkan di bawah jagaan pegawai Inggeris. Contoh pada tahun 1812 terdapat seramai 7, 000 orang India di Pulau Pinang manakala di Seberang Perai seramai 26, 000 
orang. Jumlah ini kemudiannya meningkat menjadi 8,500 orang pada tahun 1820 berbanding orang Cina yang hanya mencatat jumlah seramai 8,300 orang pada tahun yang sama. Berbanding di Singapura, jumlah penduduk Cina hanyalah 1, 150 orang sahaja pada tahun 1822 namun meningkat secara drastik menjadi 28,000 orang pada tahun 1850 . Kebanyakan orang Cina di Singapura melibatkan diri dalam aktiviti penanaman gambir dan lada hitam. Di Melaka pula penduduk India hanya dapat dikesan seramai 2,300 orang pada tahun 1826 manakala 2, 216 orang Cina pada tahun 1750 dan meningkat menjadi 4, 100 pada tahun 1826. Majoriti penduduk Cina terlibat dalam aktiviti perniagaan. Lihat, Ooi Jin Bee, Bumi, Pendudok dan Ekonomi di- Tanah Melayu, Kuala Lumpur: Dewan Bahasa dan Pustaka, 1968, hlm. 113-114.

13 Neil Khor Jin Keong \& Khoo Keat Siew, The Penang Po Leung Kuk, hlm. 36.

14 Ibid., hlm. 37.

15 Zainal Abidin Bin Abdul Wahid (dll), Malaysia: Warisan dan Perkembangan, hlm. 83.

16 Neil Khor Jin Keong \& Khoo Keat Siew, The Penang Po Leung Kuk, hlm. 39.

17 Sebelum ini, W.A. Pickering pernah dilantik sebagai jurubahasa Cina serta menyertai Straits Settlement Civil Service yang mana pertama kalinya beliau ditugaskan ke Foochow, China. Pada 1862 pula beliau menyertai Imperial Maritime Customs Department sebagai pembantu sementara dalam hal-hal di pelabuhan dan hal-hal yang berkaitan import dan export. Dengan kebolehannya yang boleh berbahasa Hokkien, Mandarin, Foochow, Teochew, Hakka dan Kantonis membuka ruang kepadanya untuk berkomunikasi dengan orang-orang Cina. Kehebatannya diakui pada tahun 1871 apabila dilihat beliau mempunyai hubungan yang rapat dengan masyarakat Cina di Negeri-Negeri Selat sehinggakan beliau berjaya menjadi "orang tengah" kepada kerajaan untuk berhubung dengan masyarakat Cina dan kongsi-kongsi gelap. Dr. N. B. Dennys dilantik sebagai Assistant Protector of Chinese Singapore pada 23 April 1877. Lihat, Ng Siew Yoong, Chinese Protectorate (1877-1900), Latihan Ilmiah, Singapore: University Malaya, 1955, hlm. 9-11.

18 Pada mulanya "kapitan" digunakan sebagai mewakili suara masyarakat Cina namun kemudiannya ditukarkan kepada Chinese Protectorate yang mana ia mengambilalih fungsi yang sama. Dengan kata lain Chinese Protectorate bertindak sebagai medium komunikasi di antara pihak kerajaan dengan masyarakat Cina. Menurut $\mathrm{Ng}$ Siew Yoong Chinese Protectorate bertanggungjawab kepada hal-hal yang berkaitan masyarakat Cina yang merangkumi cara hidup, budaya serta memastikan imigran Cina yang datang diberi hak dan perlindungan yang sewajarnya. Lihat, $\mathrm{Ng}$ Siew Yoong, Chinese Protectorate (1877-1900), Latihan Ilmiah, hlm. 9.

19 Wanita bermaksud orang perempuan yang tergolong sebagai kaum ibu. Lihat, Noresah bt. Baharom (ed), Kamus Dewan Edisi Keempat, Kuala Lumpur: Dewan Bahasa dan Pustaka, 2005, hlm. 1800.

20 Gadis membawa maksud anak perempuan yang sudah baligh, masih perawan dan belum disetubuhi. Lihat, Ibid., hlm. 421. 
Protectorate akan memberi penerangan kepada imigran-imigran baru serta turut memberi perlindungan kepada wanita dan gadis daripada cengkaman kongsi gelap. Lihat, Neil Khor Jin Keong \& Khoo Keat Siew, The Penang Po Leung Kok, hlm. 38-39. tahun 1900-1941, (Disertasi Sarjana), Kuala Lumpur: Universiti Malaya, 1998, hlm. 38.

24 Enterprise, 1992, hlm. 7.

25 Tanpa pengarang, Prostitutes and Prostitution in Malaya Between the 1880's and 1930's, hlm.1.

36 CO273/ Vol. 453, Prostitution in the Colony.

$v$ James Francis Warren, Ah Ku and Karayuki-san: Prostitution in Singapore 1870-1940, Singapore: Singapore University Press, 2003, hlm. 40.

as CO273/Vol. 453, Prostitution in the Colony, 1916.

2 Ibid.,

30 lbid.,

31 Ibid.,

3 James Francis Warren, Ah Ku and Karayuki-san: Prostitution in Singapore 18701940, hlm. 1.

33 Lenore Manderson, Sickness and the State: Health and Illness in Colonial Malaya 1870-1940, hlm. 167.

34 Wanita Cina ini memberikan perkhidmatannya kepada kaum lelaki Cina yang mana di Singapura tempat memberikan perkhidmatan adalah di Chinese Street dan Smith Street. Lihat, Lenore Manderson, Sickness and the State: Health and Illness in Colonial Malaya 1870-1940 , hlm. 168.

35 Golongan wanita berbangsa Eropah yang melibatkan diri dalam kegiatan pelacuran adalah daripada kalangan mereka yang datang dari German, Hungary, Austria dan Rusia. Di Singapura, golongan ini memberikan perkhidmatan di kawasan Malay Street-North Brigde Road yang mana majoriti pelanggan adalah di kalangan lelaki Eropah. Lihat, Lenore Manderson, Sickness and the State: Health and Illness in Colonial Malaya 18701940, hlm. 168.

36 Ibid., hlm. 168.

3 lbid.,

36 Ibid.,

99 Gerald J. Stine, The Biology of Sexually Transmitted Disease, University of North Florida: Wm. C. Brown Publishers, 1992, hlm. xvii.

* Gonorea merupakan penyakit kelamin yang disebabkan oleh kuman Neisseria Gonorrhea. Penyakit ini digolongkan sebagai VD dan STD yang mempunyai masa eraman atau inkubasi (incubation) antara 48 jam selama lima hari. Kajian rambang menunjukkan hampir 80 peratus daripada pelacur yang diperiksa membawa penyakit ini tanpa merasakan sebarang gejala. Lihat, Rahmat Haroun, Sifilis dan Penyakit Kelamin Lainnya, Kuala Lumpur: Penerbit Fajar Bakti, 1992, hlm. 8-9. 
41 Jika profesion tertua ialah pelacuran, sifilis adalah setua profesion itu. Penyakit ini dikenali sebagai 'Raja Singa' yang dijangkiti melalui hubungan seks. Lihat, Rahmat Haroun, Sifilis dan Penyakit Kelamin Lainnya, hlm. 5. Sifilis digambarkan sebagai ketumbuhan ulser yang lembut pada bahagian kemaluan lelaki dan wanita, mulut, anak tekak dan hidung. Lihat, Gerald J. Stine, The Biology of Sexually Transmitted Disease, hlm. 257.

42 Ibid., hlm. 16.

43 Lenore Manderson, Sickness and the State: Health and Illness in Colonial Malaya 1870-1940, hlm. 178.

4 Yen Ching-Hwang, A Social History of the Chinese and Malaya 1800-1911, Singapore: Oxford University Press, 1986, hlm. 254.

45 CO 273/ Vol. 478, Ass of Moral and Social Hygience: Public Prostitution in Straits, 1819.

46 CO 273/Vol. 187, Prostitutes: Examination and Treatment, 1893, hlm. 78-81. 